\title{
Метилтрансферазы растений
}

\author{
Е. Н. Тищенко, О. В. Дубровная \\ Институт физиологии растений и генетики НАН Ухраины \\ Ул. Васильковская, 31/17, Киев, 03022, Ухраина \\ E. mail: plant@ifrg.freenet.kiev.ua
}

В обзоре обобщены современные данные о цитозин-С5-ДНК метилтрансферазах растеншй. Oхарактеризованы три различных класса этих ферментов-DnmtI/METI, Dnmt3 и CMT. обсухдается их предполагаемая функция, связанная с поддерхиваюицм метилированием и метилированием dе поvо остатков цитозика в симметрииных и асимметричных мотивах дНК.

Клочевые слова: метилировани, цитозин, метилтрансферазы

Введение. Метилированию ДНК отводится важная роль в функциональной геномике эукариотов. Ферментативная модификация цитозина рассматривается в качестве одной из основных детерминант эпигенетической регуляции экспрессии тенов и трансгенов растений. Ее предполагаемая функция также состоит в инактивации повторякщихся последовательностей, защищая таким образом геном or распространения мобильных генетических элементов и чужеродной генетической информации. Немаловажное значение уделяется метилированию ДНК в явлениях импринтинга, парамутаций, полиплоидизации, в механизмах дифференцировки клеток в процессе развития растений и их генетической нестабильности.

Отличительной чертой ддерной ДНК растений является высокий уровень ее метилирования: она может содержать до 40-50 \% модифицированных остатков цитозина в симметричных ( $\mathrm{CpG}, \mathrm{CpNpG}$, где $\mathrm{N}$ - любое основание, олличное от гуанина) и асимметричных (CpNpN) мотивах, тогда как у животннх - не более $8 \%[1,2]$. Принципиальное значение имеет расшифровка механизмов de поvo и поддерживающего метилирования ДНК эукариотов - двух основных процессов метилирования,

(C) в. Н. тИLЕНКО, О. в. ДУБРОВНАЯ, 2005 ключевое положение в которых занимают ферменты цитозин-С5-ДНК метилтрансферазы (метилтрансферазы). При поддерживаюцем метилировании его паттерны в $\mathrm{CpG}$ и $\mathrm{CpNpG}$ мотивах передаются в обе дочерние нити метилтрансферазами, которые в реплихативной вилке преимущественно метилируют полуметилированную ДНК, тогда как при de novo метилировании ферментативной модификации подвергаются ранее неметилированные остатки цитозина. Для симметричных последовательностей достаточно, чтобы метилирование $d e$ поvо произошло один раз, после чего ферментативная модификация мохет осуществляться за счет активности поддерживающих метилтрансфераз. Однако для поддержания метилирования в асимметричных сайтах метилирование de novo должно иметь место при каждом цикле клеточного деления [1]. Механизмы метилирования ДНК далеки еще от полного понимания. До недавнего времени, пока были клонированы только гены Dnmtl животных, оставался открытым вопрос, кодируются ли метилтрансферазы семействами генов, выполняюдих разные функции, связанные с модифихациями $\mathrm{CpG}, \mathrm{CpNpG}$ и $\mathrm{CpNpN}$ последовательностей. Кpoме того, вообще было неизвестно, какие ферменты способны осуществлять de novo модификацию цитозина в асимметричных последовательностях. В 
последнее время, после идентификации вначале в геномах растений, а затем и животных множественных генов метилтрансфераз, в этой области исследований достигнут значительный прогресс.

Общая характеристика метилтрансфераз. На текущий момент, основываясь на гомологии аминокислотных и/или полинуклеотидных последовательностей, а также на предполагаемой функции, метилтрансферазы растений и животных сгруппированы, по крайне мере, в четыре различных класса: Dnmt1/MET1, Dnmt2, Dnmt3 и CMT [37]. Последний харахтерен только для растений. Считается, что Dnmt2-класс представлен пока что метилтрансферазами животных, однако в литературе имеются сведения о том, что у арабидопсиса идентифицирована полинуклеотидная последовательность, способная кодировать полипептид, помологичный белку Dnmt2 животных [4]. Возможно, что этот класс имеется и у растений.

Данные о полифункциональных метилтрансферазах растений обобщены в таблице. Есть основания считать, что поддерживающее метилирование в симметричных $\mathrm{CpG}$ и $\mathrm{CpNpG}$ последовательностях растений осуществляют главным образом метилтрансферазы класса Dnmt1/MET1 и CMT coorветственно, в то время как за de nоvo ферментативную модификацию цитозина симметричных и асимметричных мотивов ответственны ферменты класcа Dnmt3 [4-7].

Метилтрансферазы про- и эукариотов катализируют реакцию переноса метильных групп с Sаденозил-L-метионина (SAM) в C5 положение пиримидинового кольца цитозинового остатка с образованием промежуточного ковалентного комплекса ДНК-белок. Конечным продуктом этой реакции являются 5-метилцитозин и $\mathbf{S}$-аденозилгомоцистеин. Во всех изученных цитозин-С5-ДНК метилтрансферазах в С-концевой области представлены консервативные мотивы аминокислотных последовательностей, которые собственно и выполняют каталитическую функцию фермента: Они расположены во многих метилтрансферазах одним и тем же упорядоченным образом и разделены, как правило, неконсервативными аминокислотными последовательностями вариабельной длины. Большинство метилтрансфераз эукариотов включает консервативные мотивы VIII и $\mathrm{X}$ прокариотов, причем мотивы VII и VIII не являются высококонсервативными и поэтому их трудно различать во многих ферментах $[1,3-18]$.
Наиболее изученными являются метилтрансферазы прокариотов, для которых показано, что консервативные мотивы I и X образуют сайт связывания донора метильных группа, остаток цистеина дуплета пролин-цистеин мотива IV формирует активный центр, ответственный за перенос метильной группы. При этом вариабельная аминокислотная последовательность TRD (target-recognizing domain) между мотивами VIII и IX направляет фермент к последовательности узнавания, фланкирующей цитозин, который подвергается метилированию $[1,3]$.

У ряда изученных метилтрансфераз эукариотов участок с консервативными мотивами слит с большой регуляторной $\mathrm{N}$-аминотерминальной областью, отсутствующей у прокариотов $[1,3,4,18]$. Такая область впервые идентифицирована в метилтрансферазе Dnmtl мыши. Обнаружена она и в первом клонированном гене метилтрансфераз растений - METI арабидопсиса, а впоследствии - и в других генах классов Dnmtl/METI, CMT [1, 6, 19]. N-аминотерминальная область выполняет функции, включающие, в частности, направление метилтрансферазы в репликативную вилку во время $\mathrm{S}$ фазы клеточного цикла $[4,21,22]$.

Сведения о том, каким образом происходит пострепликативное метилирование ДНК, ограничены и касаются в основном животных. Для точного воспроизведения паттернов метилирования в клеточном цикле предполагается, что оно должно быть сопряжено с репликацией ДНК. Для этого есть следуюцие основания: экспрессия гена DNMTI регулируется в клеточном цикле; эта метилтрансфераза локализована в репликативной вилке; метилирование осуществляется согласованно с репликацией ДНК; ингибирование DNMTI может приводить к подавлению инициации репликации ДНК $[21,23]$. Однако молекулярные детерминанты этого взаимодействия еще не определены. Тем не менее, установлено, что DNMT1 является компонентом мультибелкового комплекса репликации ДНК, названного ДНК-синтесомой, который в бесклеточной системе полностью поддерживает полуконсервативную репликацию ДНК. Связанный с синтесомой фермент демонстрирует как поддерживающую, так и с низким уровнем de novo метилтрансферазную активность. Полученные данные указывают на то, что метилирование ДНК прочно сопряжено с репликацией через физическое взаимодействие DNMT1 и кор-компонентов реплика- 
Цитозин-С5-ДНК-метилтрансферазы растений и их предполагаемая функиия

\begin{tabular}{|c|c|c|c|}
\hline $\begin{array}{l}\text { Knax ферментов } \\
\text { Hasashue reza }\end{array}$ & Oрганизм & Прехполагаемах фуякиих & Источник литературы \\
\hline Dnmt1/MET1 & & ' & \\
\hline \multirow[t]{2}{*}{ METI (DDM2) } & Арабидопсис & $\begin{array}{l}\text { Подлерживаощая CpG в уникальньх и повторя- } \\
\text { ющихся последовательностях }\end{array}$ & {$[1,4,7]$} \\
\hline & & $\begin{array}{l}\text { Непрямое участие в метилировании CpNpG и } \\
\text { CpNpN? }\end{array}$ & {$[5,30]$} \\
\hline METIIa, METIIb, METIII & Арабидопсис & ГІоддерживаюцая? & {$[9,4]$} \\
\hline MetI, Met2 & Морковь & Поддерживающая & {$[10]$} \\
\hline PMET & Горох & Поддерживающая CpG, CNG & [11] \\
\hline ZmMETI & Кукуруза & Поддерживающах & {$[12]$} \\
\hline NtMETl & Taбax & Поддерживающая & [20] \\
\hline OSMETI-I, OsMET1-2 & Puc & Поддерживающая & [19] \\
\hline PDMET1 & Персик & Поддерживакщцая & [35] \\
\hline \multicolumn{4}{|l|}{ Dnmt3 } \\
\hline$D R M 1$ и $D R M 2$ & Арабидопсис & $\begin{array}{l}\text { Метилирование CpG, CpNpG и CpNpN de novo. } \\
\text { Поддерживающая CpNpN и CpNpG в некоторьхх } \\
\text { локусов }\end{array}$ & {$[5,13]$} \\
\hline Zmet3 & Кукуруза & de novo & {$[13]$} \\
\hline NtDRMI & Tabak & de novo & [5] \\
\hline \multicolumn{4}{|l|}{ CMT } \\
\hline ZMET2 & Кукуруза & Поддерживакщая $\mathrm{CpNpG}$ & [6] \\
\hline ZMETS & Кукуруза & Подлерживающая CpNpG? & [6] \\
\hline CMTI & Арабидопсис & Гетерохроматин? Несущественна & [4] \\
\hline$C M T 2$ & Арабидопсис & Гетерохроматин? & [4] \\
\hline CMT3 & Арабидолсис & Подлерживающая $\mathrm{CpNpG}$ и частично - $\mathrm{CpNpN}$ & [5] \\
\hline
\end{tabular}

П р и ме ч а в и е. $\mathrm{CpG}, \mathrm{CpNpG} \mathrm{-} \mathrm{симметричные,} \mathrm{CpNpN}$ - асимметричные мотивы.

тивного комплекса [24]. Поскольку DNMT1 присутствует в репликативной вилке, возникает вопрос о том, происходит ли метилирование в ДНК перед ее упаковкой в нуклеосомы, которые образуются очень быстро вслед за репликативной вилкой? Для 5S рДНК обнаружено, что DNMT1 способна метилировать ряд $\mathrm{CpG}$ сайтов, даже когда большая бороздка ориентирована по направлению $\mathrm{x}$ поверхности гистонов. Вместе с тем способность этого фермента модифицировать нуклеосомные сайты весьма зависима от природы субстрата [25].

Метилтрансферазы растений класса Dnmt1/MET1. Arabidopsis thaliana- первый вид растений, в котором, используя гомологию между консервативными мотивами IX и X прокариотных и мышиных метилтрансфераз, методами полимеразной цепной реакции (ПЦР) и скрининга библиотеки кДНК идентифицированы кДНК, относящи- еся к семейству генов метилтрансфераз МET 1 (DDM2). Кроме того, именно для этого вида показано, что метилтрансферазы эукариотов могут кодироваться определенным семейством генов $[1,7]$.

Первыми были выделены гены METI и METII и показано, что они, как и Dnmtl животных, содержат $\mathrm{N}$-аминотерминальную регуляторную область. Гомология между их белками оказалась более высокой в С-метилтрансферазной области, чем в $\mathrm{N}$-аминотерминальной, притом что степень дивергенции между этими белками была больше по сравнению с таховой между Dnmtl мыши и человека. METI и Dnmtl имеют $50 \%$ гомологичных аминокислотных последовательностей в каталитической области фермента, тогда как в регуляторной $-24 \%$. На данный момент семейство генов METI включает пять представителей, четыре из которых частично охарактеризованы [4]. Два гена, 
METIIa и METIII, тесно сцеплены, тогда как два других - METI и $M E T I I b-$ находятся в различных локусах. Предполагается, что эти гены произошли от общего предка через серию его дупликаций. Несвязанные гены $M E T I I a$ и $M E T I I b$ наиболее подобны друг другу и, по-видимому, являются продуктами недавних дупликаций.

В N-аминотерминальной регуляторной области METI последовательно, через определенные интервалы располагаются предполагаемый сигнал ядерной локализации, а также домен, ответственный, вероятно, за направление этого фермента в репликативную вилку, так называемая «кислая» область. Как и у животных, N-терминальная область MET1 арабндопсиса отделена от С-метилтрансферазной области чередующимися остатками аминокислот лизин-глицин [4, 7]. «Кислая» область состоит, по крайней мере, из $50 \%$ остатков глутаминовой и аспарагиновой кислот и в пределах N-терминальной области ферментов класса MET1 расположена в одном и том же положении. Роль этих областей неизвестна. Среди ферментов растений наименее консервативной является TRD область [4].

Выявлена гомология аминокислотной последовательности (остатки 207-455), направляющей метилтрансферазу Dnmt1 мыши в репликативную вилку, с последовательностью (120-280) белка METI арабидопсиса. Это позволило предположить аналогичную функцию и для растительных метилтрансфераз [1].

Следует отметить, что первоначальные исследования метилтрансфераз растений и животных на биохимическом уровне показали некоторые отличия между ними. Первым свойственна относительно высокая скорость как поддерживающего, так и de novo метилирования, в то времs как вторым преимущественно поддерживающее метилирование. По этой характеристике метилтрансферазы растений более сходны с аналогичными ферментами прокариотов. В $\mathrm{N}$-аминотерминальной регуляторной области Dnmt1 идентифицированы последовательности, подавляющие метилазную активность de novo. Этим, видимо, и объясняется предпочтительное метилирование полуметилированных мотивов ДНК животных [21].

Особенностью метилтрансфераз Dnmtl/MET1 арабидопсиса является отсутствие в их белках обогащенното цистеином цинк-связывающего домена, что характерно для $\mathrm{N}$-терминальной области белков животных [21]. Возможно, этим и определяет- ся de novo метилазная активность вышеупомянутого фермента растений [7]. В отличие от животных, у растительных метилтрансфераз отсутствуют делеции из 40-41 аминокислотных остатков в области узнавания, а также для них характерно наличие «кислой» области [4].

Фермент МЕТ1 выполняет главным образом поддерживающее метилирование ДНК арабидопсиса. Об этом свидетельствуют исследования, с одной стороны, транстенных растений арабидопсиса с интродуцированной кДНК $M E T I$ в антисмысловой ориентации под контролем промотора $35 \mathrm{~S}$ вируса мозаики цветной капусты, а с другой, - мутантов этого гена - met1. Экспрессия «антисмыслового» трансгена приводит к снижению уровня метилирования ДНК в пределах 34-71 \% в большинстве CpG мотивов, а также (хотя и с меньшим эффектом) в тринуклеотидах $\mathrm{CpNpG} \mathrm{[26,} \mathrm{27].} \mathrm{Потеря}$ метильных групп в $5 \mathrm{meC}$ происходит как в повторяющихся, так и уникальных последовательностях ДНК. Охарактеризованы две миссенс-мутации гена метилтрансферазы MET1 арабидопсиса, мутантные аллели которого названы metl-I и met1-2 [28]. Точечные мутации в обоих аллелях, обусловленные заменой пары CG на АТ в экзонах генов, затрагивают С-терминальную каталитическую область фермента, в результате чего глобально уменьшается уровень метилирования ДНК. Аллель met $I$-I является миссенс-мутацией, в которой остаток серина замещен на пролин. Мутация metl-l не изменяет консервативных мотивов белка метилтрансферазы MET1. В то же время мутация met 1-2 обнаружена в консервативном мотиве I, причастном К связыванию донора метильных групп, и приводит к замене инвариантното глицинового остатка, существенного для каталитической активности фермента, на серин. Удивительно, но, судя по уровню метилирования ДНК, аллель metl-2 является более слабым по сравнению с met 1-1. Следует отметить, что оба этих аллеля одинаково влияют на ферментативную модификацию цитозина в ДНК рибосомных генов, а различия в уровне метилирования генома арабидопсиса обусловлены, главным образом, повторяющимися последовательностями центромер. За счет чего проявляется различный эффект, непонятно, но, тем не менее, такие данные указывают на участие метилтрансферазы MET1 в выборе мишени для метилирования.

Первоначально считали, что МЕT1 осуществляет преимущественное метилирование симметрич- 
ного динуклеотида $\mathrm{CpG}$ [1]. В последнее время методом секвенирования с использованием бисульфита натрия показано, что в мутантах met $l-1$ может происходить потеря метилированных остатков цитозина не только в тринуклеотиде CpNpG, но и в асимметричных последовательностях [28 ]. У мутантов met $1-1$ уменьшение уровня метилирования в асимметричных мотивах может быть следствием потери симметричных $\mathrm{CpG}$ динуклеотидов [5]. Все это указывает на более широхую субстратную специфичность последовательностей для метилтрансферазы MET1 [28].

Ранее такая возможность метилтрансфераз растений класса Dnmtl/MET1 подтверждена результатами изучения in vitro экспрессии гена PMET rороха в бакуловирусе [11].

Следует отметить, что хотя МЕТ1-семейство генов арабидопсиса гомологично метилтрансферазам Dnmtl животных, растения арабидопсиса со сниженным уровнем метилирования являются, в отличие от Dnmtl-мутантов мыши, жизнеспособными несмотря на то, что у них выявлен ряд аномалий в развитии $[1,26,27,29]$. Уменьшение содержания $5 \mathrm{meC}$ связажо с аберрантной экспрессией генов, в том числе некоторых регуляторных генов морфогенеза $[1,26,27]$. И, наоборот, возможно эктопическое гиперметилирование ряда генов, например, SUPERMAN, AGAMOUS арабидопсиса. По мнению Финнегана и соавт. [1 ], тот факт, чтo de novo ферментативная модификация цитозина может стимулироваться глобальным гипометилированием ДНК, предполагает использование растемиями этой эпигенетической детерминанты для защиты против факторов, нарушающих нормальную организацию генома.

Функции остальных белков МЕТ1-семейства - METIIa, METIIb и METIII еmе не определены. Данные о предполагаемой роли МЕTIII противоречивы, этот фермент, по-видимому, играет незначительную роль в метилировании ДНК [4].

Множественность генов метилтрансфераз растений класса Dnmtl/MET1 в дальнейшем подтверждена и для других растительных объектов - моркови, гороха, риса $[1,11,19]$. В частности, в геноме моркови обнаружены два гена, Metl и Met2, которые, являясь продуктами независимых дупликаций, имеют бо́льпую степень гомологии $\mathrm{k}$ METI, чем к METII арабидопсиса, в метилтрансферазной области. Предполагается, что оба они являкотся гомологами $M E T I$, однако располагаются в разных локусах. Больший размер Met2 обусловлен присутствием в его последовательности пятикратно повторяющегося элемента размером 171 пара нуклеотидов (п. н.). В работе Берначиа и соавт. [10] иммунологическим методом показано, что метилтрансферазы эукариотов кодируются семейством генов. В геноме риса идентифицированы два гена - OsMET1-I (на хромосоме 3) и OsMETI-2 (на хромосоме 7), первый из которых содержит 12 экзонов и 11 интронов, тогда как второй - 11 экзонов и 10 интронов. Хотя в целом для обоих генов выявлена высокая степень гомологии, для экзона 1 установлена лишь $24 \%$-я идентичность и показано, что в OsMET l-2 отсутствует интрон 3 гена OsMETI-1. Как и в других белках класса Dnmt1/MET1, две трети аминокислотных последовательностей OsMET1-1 и OSMET1-2 составляет $\mathrm{N}$-терминальная регуляторная область [19].

Хромометилазы СМТ растений. Следуюций класс метилтрансфераз растений - хромометилазы СМТ. Среди известннх ферментов, катализирующих реакцию метилирования ДНК эукариотов, класс СМТ является специфичным для растений. Его структурной особенностью является наличие хромодомена - короткого мотива, впервке обнаруженного в хроматин-связывающих белках дрозофилы (Hp1 и Polycomb) [1, 4, 6, 31 ]. CMT найдены как у однодольных, так и у двудольных растений. Предполагается, что хромометилазы принадлежат к специализированному типу поддерживающих метилтрансфераз, предоставляющих растительному геному другую возможность для распространения метилированных остатков цитозина, а именно метилирование симметричных $\mathrm{CpNpG}$ и/или асимметричных последовательностей $[5,6,13]$. Описано несколько мутантов арабидопсиса по гену $C M T 3$ и показано, что отсутствие функциональной активности этого гена приводит $k$ обширной потере метильных групп в $5 \mathrm{meC}$ pNpG-мотивах, а также к снижению уровня метилирования асимметричных сайтов в некоторнх локусах $[5,32]$. Фермент СМТ может контролировать, в частности, метилирование ретротранспозона Та3 и центромерных повторов размером 180 п. н. арабидопсиса, а также осуществлять ферментативную модификацию цитозина асимметричных последовательностей одного из его локусов - SUPERMAN [5].

Существует мнение, что CMT3 преимущественно метилирует родственные транспозонам последовательности [37]. Что касается гена ZMET2, 
то для изучения его функции были получены гомозиготные растения кукурузы со встроенным в консервативный мотив IX транспозонным элементом Mutator. Показано, что гипометилирование происходило только в тринуклеотиде $\mathrm{CpNpG}$, тогда как уровень ферментативной модификации $\mathrm{CpG}$ и асимметричных мотивов ДНК не изменялся [6]. Это свидетельствует о возможной специфичности метилирования мотивов ДНК, отличных от $\mathrm{CpG}$, для метилтрансфераз типа СМТ двудольных и однодольных растений.

Аминокислотные последовательности СМT, как и таковые других метилтрансфераз, содержат консервативные элементы, характерные для каталитической С-терминальной области. Однако они отличаются по организации консервативных метилтрансферазных мотивов и по структуре N-терминального регуляторного домена. В последнем отсутствует $~ 750$ аминокислотных остатков, обнаруженных в белках Dnmt1/MET1-класса метилтрансфераз. В то же время известные хромометилазы по размеру аналогичны Dnmt3-классу [6 ].

Сравнительное изучение аминокислотных последовательностей хромометилаз кукурузы ZMET2, ZMET5 и арабидопсиса CMT1 CMT2 CMT3 выявило наличие консервативных I, IV, VI, VIII, IX и X мотивов. Хромообласть обычно локализуется между мотивами I и IV. N-терминальные области хромометилаз содержат также серии убиквитин-связанных (UBA) доменов. Кроме того, все хромометилазы содержат ВАН область (bromo adjacent homology), которая в геномах животных имеет отношение к взаимосвязи метилирования и репликации, а также к регуляции транскрипции [6, 13]. В отличие от хромометилаз обе метилтрансферазы класса Dnmt1/MET1 (MET1 и ZMET1) содержат два ВАН домена в $\mathrm{N}$-терминальной регуляторной области. На основании этого предполагается, что хромометилазы и ферменты типа MET1 произошли от общего предшественника [13]. Исключительное присутствие хромометилаз в растениях позволяет обьяснить более высокий уровень метилирования их $\mathrm{CpNpG}$ последовательностей по сравнению с одноименными сайтами ДНК животных [6].

С помощью филогенетического анализа показано, что белки ZMET2 и ZMET5 являются более близкородственными к CMT1 и СМТ3, чем к CMT2. N-терминальная область ZMET2 меньше таковой в Dnmtl/MET1 классе метилтрансфераз, тем не менее, в ней содержится предполагаемый сигнал ядерной локализации. Кроме того, аминокислотные последовательности хромодоменов являются консервативными для ZMET2 и СMT1.

На ферментативную модификацию цитозина в тринуклеотидах $\mathrm{CpNpG,} \mathrm{по-видимому,} \mathrm{оказывает}$ влияние метилирование Lys9 гистона Н3. Показано, что Swi6, гомолог HP1, напрямую взаимодействyет c Lys9 гистона Н3 [33] и что мутация гена kryptonite Arabidopsis thaliana, кодирующего гистоновую метилтрансферазу, приводит к потере метилирования ДНК [34]. Механизм, лежащий в основе такой зависимости метилирования ДНК от модификации гистона, еще не ясен. Тем не менее, адаптерный белок LHP1 арабидопсиса, способный связываться с гистоном Н3 при метилировании Lys9, взаимодействует с метилтрансферазой СМТ3. Следует отметить, что известные данные о последовательности метилирования Lys9 гистона Н3 и симметричных мотивов ДНК противоречивы. Так, в частности, в работе [36] показано, что в нульмутантах арабидопсиса по гену $M E T I$ полное отсутствие метилирования $\mathrm{CpG}$ мотивов в гетерохроматине приводит к потере метилирования лизина.

Класс метилтрансфераз растений Dnmt3. У растений, как и у животных, метилирование ДНК de novo, по всей видимости, осуцествляют ферменты класса Dnmt3. Идентифицированы гены $D R M I$ и $D R M 2$ арабидопсиса, Zmet3 кукурузы, NtDRMI табака $[5,8,13]$. В отличие от описанных выше ферментов, в белках DRM2 (DRM - Domains Rearranged Methylase) и Zmet3 наблюдается перестройка консервативных каталитических мотивов. Большинство метилтрансфераз, включая Dnmt3 животных, содержат мотивы I-VI, IX и X от N- к C-терминальной области белка. Однако в аминокислотных последовательностях этих ферментов арабидопсиса и кукурузы наблюдается измененное расположение консервативных мотивов, а именно - VI, IX, X, I-V. Для метилтрансфераз перестройка консервативных элементов каталитической области не ограничивается растениями. Так, для бактериальной метилтрансферазы ( $\phi)$ BssHII показано, что мотивы IX и X предшествуют I-VIJI, в то время как в AquI мотивы IX и X локализованы в отдельной субъединице $[13,15]$. Тот факт, что такие прокариотные ферменты не утрачивают метилтрансферазной активности, свидетельствует о том, что обычное расположение консервативных элементов несущественно для их функции [13].

Идентичность аминокислотных последователь- 
ностей генов белков DRM и Zmet3 составляет $66 \%$ в С-терминальной, и только $28 \%$ - в N-терминальной областях. Кроме того, они содержат несколько аминокислотных последовательностей, являющихся, как полагают, критическими для функционирования цитозиновых метилтрансфераз. Так, Phe-Gly-Xaa-Gly-ocratки входят в состав мотива I, связывающего SAM, инвариантный дипептид ProCys каталитического центра - в мотив IV, GluAsn-Val остатки - в мотив узнавания VI. Считается, что DRM2 и Zmet3 являются функциональными метилтрансферазами. Они содержат в N-терминальных областях серии UBA доменов, функция которых неясна. Предполагается, что эти домены могут обеспечивать взаимосвязь между метилированием ДНК и убиквитин/протеосомными путями [13].

K метклтрансферазам, осуществляющим de novo метилирование преимущественно в последовательностях, отличных от $\mathrm{CpG}$ мотивов, относится также NtDRM1 пабака. Ген этого фермента кодирует белок из 608 аминокислотных остатков, в котором имеются области, аналогичные DRM кукурузы и арабидопсиса [8]. Показано, что этот белок локализован исключительно в ядре и проявляет метилазную активность к неметилированным как синтетическим, так и нативным ДНК. Он также ферментативно модифицирует полуметилированную ДНК, но его активность значительно ниже, чем для неметилированного субстрата. Эксперименты in vitro показали, что приблизительно $70 \%$ остатков цитозина метилируется в асимметричных $\mathrm{CpNpN}$ и симметричных $\mathrm{CpNpG}$ мотивах, тогда как в динуклеотиде $\mathrm{CpG}$ - только $10 \%$. Этот фермент неселективно метилирует любые остатки цитозина безотносительно к смежным нуклеотидам с обоих (5' и $\left.3^{\prime}\right)$ концов, за исключением СpG мотивов,

Одна из функций генов $D R M I$ и $D R M 2$ арабидопсиса - метилирование de поvо цитозина во всех известных контекстах последовательностей: $\mathrm{CpG}$, $\mathrm{CpNpG}, \mathrm{CpNpN}$. Для последних показано предпочтительное метилирование СрА и СрТ сайтов по сравнению с СрС. Об этой функции ферментов свидетельствует анализ ряда генов в мутантах по двум генам - $d r m 1, d r m 2$. В частности, не происходит инициирующего метилирования прямых повторов локуса $F W A$, которое обычно имеет место при трансформации $F W A$ в растения дикого типа. В двойных мутантах также блокируется de novo метилирование локуса $S U P E R M A N$, осуществляемое в присутствии инвертированного повтора этого гена [13]. Однако в мутантах $d r m$ не наблюдается реактивации предварительно метилированных и эпигенетически молчащих аллелей SUPERMAN и $F W A$. Поэтому предположено [13], что $D R M$ гены необходимы для установления, а не для поддержания молчания генов.

В дальнейшем было показано, что гены $D R M$ могут выполнять поддерживающее метилирование асимметричных последовательностей и $\mathrm{CpNpG}$ мотивов ДНК [5]. Однако в некоторых локусах, таких как SUPERMAN, метилтрансферазы DRM функционируют совместно с CMT3, поскольку лишь в триплетных мутантах $\mathrm{drm} / \mathrm{drm} 2 \mathrm{~cm} t 3$ терякося метилированные остатки цитозина во всех асимметричных последовательностях. Более того, в некоторнх локусах для поддержания метилирования тринуклеотидов CpNpG ферменты DRM являются более важными, чем СМТЗ. По предположению Кейо и соавт. [5], гены $D R M$ и CMT3 функционируют избыточно и локус-специфичным образом для осуществления контроля метилирования в асимметричных и $\mathrm{CpNpG}$ мотивах.

Кроме вышеизложенного, участие метилтрансфераз DRM и CMT3 показано в PHK-направленном метилировании ДНК (RdDM, RNA-directed DNA methylation, процесc de novo метилирования последовательностей ДНК, идентичных тригтерным двунитчатым РНК разных источников, в частности, вирусов, трансгенов, транспозонов) [38, 39]. Установлено, что ни $d r m$, ни $c m t 3$ мутации не влияют на поддержание предварительно установленного РНК-направленного метилирования $\mathrm{CpG}$ мотивов. Однако в $\mathrm{drm}$ мутантах происходит почти полная потеря метильных групп в асимметричных и частичная - в $5 \mathrm{meCpNpG-последовательностях.}$ Поддержание метитирования в остальных не- $\mathrm{CpG}$ мотивах зависело от активности СМТ3, что свидетельствует о совместном действии DRM и CMT3 при РНК-направленном метилирования дНК [38]. Следует отметить, что, по-видимому, эти ферменTh проявляют функциональную активность после образования коротких интерферирующих РНК (siRNA), которые, как известно [40], являются результатом процессинга двунитчатых $\mathrm{PHK}$, поскольку в триплетных мутантах $\mathrm{drm} I \mathrm{drm} 2 \mathrm{cmt} 3$ выявлено отсутствие не-CpG-метилирования при повышенном уровне siRNA [38 ]. Кроме тот,, показано, что активность ферментов DRM необходима 
для de novo метилирования во всех контекстах мотивов ДНК [38].

Эхспрессия генов метилтрансфераз растений. Больпинство известных генов метилтрансфераз растений экспрессируются повсеместно как в вегетативных, так и в генеративных органах, однако проявляют более высокий уровень экспрессии в меристематических тканях $[7,10,26]$. Разные члены семейства генов могут экспрессироваться дифференциально. Так, транскрипты $M E T I$ по крайне мере в 10000 раз более избыточны, чем $M E T I I$, в вегетативных и репродуктивных органах [1]. Хотя гены метилтрансфераз моркови максимально экспрессируются в пролиферирующих клетках (меристемы, примордии листьев, клетки суспензии), существуют количественные и пространственные различия в их экспрессии. Так, мРНK MetI равномерно распределена в вегетативных апексах побегов и примордиях листьев разного возраста, в то время как присутствие мРНК $M$ et2 ограничено апихальными меристемами и самыми молодыми примордиями листьев. На более поздних этапах развития ген Met2 не функционирует. При соматическом эмбриогенезе моркови оба гена представлены равномерно на стадии глобулы и сердца, тогда как на стадии торпеды мРНК Met2 (в отличие or мРНK Metl, равномерно распределенной в продольных секциях) в основном сконцентрирована в меристемах побега и корня. В зиготических зародышах развивающихся семян наблюдается аналогичная модель экспрессии этих генов [10]. Оба гена метилтрансфераз риса класса Dnmt1/MET1 экспрессируются в активно делящихся клетках, однако стационарный уровень мРНК OsMET I-2 в корнях, соцветиях и каллусах в $7-12$ раз больше, чем мРHK OsMETI-I [19]. Транскрипты гена NtDRMI табака повсеместно накапливаются во всех тканях и во время клеточного цикла в культивируемых ВY2-клетках [8].

мРНK гена DRM2 также обнаружена во всех основных тканях кукурузы [13]. Экспрессия гена ZmMET1 кукурузы происходит исключительно в активно пролиферирующих клетках апексов [8]. Это предполагает связь транскрипции ZmMETI гена с репликацией. Подтверхдением этому служит одновременное уменьшением транскриптов ZmMETI и гистона Н3, являющегося маркером репликации ДНК, в проростках при их поранекии и засолении, когда подавляется клеточное дёление. Холодовый стресс также резко снижает экспрессию этих генов в клетках корней. Однако этот фактор окружающей среды не оказывает влияния на накопление транскриптов ZmMET1 в мезокотиле побега, в то время как транскрипция гена гистона Н3 резко падает. Дифференциальное накопление транскриптов ZMMETI совпадает с уровнем содержания его белка, определенного вестерн-блотингом. Холод индуцирует деметилирование ДНК в областях As/Ds транспозонов, но не в других генах, причем тахое деметилирование первоначально происходит в корнях. Эти результаты свидетельствуют о том, что экспрессия гена $Z$ IM не зависит полностью от репликации ДНК, и уровень метилирования ДНК уменьшается селективно при холодовом стрессе. Показано, что DRM2 экспрессируется в листьях, корнях, соцветиях растений арабидопсиса, в то время как в этих же тканях посредством РНК-блот-анализа не обнаружено мРHK DRMI, что предполагает значительно более низкий уровень экспрессии гена $D R M l$, чем DRM2 [13].

Таким образом, на сегодня в растениях обнаружены три полифункциональных класса цитозинC5-метилтрансфераз - Dnmt1/MET1, Dnmt3 и CMT, которые, по-видимому, осуществляют поддерживающее метилирование и метилирование de novo симметричных и асимметричных последовательностей генома. Метилтрансферазы класса Dnmt1/MET1 преимущественно метилируют CpG мотивы, тогда кақ хромометилазы СМТ класса CpNpG последовательности ДНК. Ферментативная модификация цитозина de novo как симметричных, тах и асимметричных мотивов генома происходит при участии метилтрансфераз класса Dnmt3.

\section{E. N. Tishchenko, O. V. Dubrovnaya}

Methyltransferases of plants

Summary

In the review the current data on the plant cytosine-C5-DNA methyltransferases (methyltransferase) are summarized. Three different classes of these enzymes - Dnmt1/METI, Dnmt3 and CMT are discribed. The proposed function, dealing with maintenance and de novo methylation of cytosine residues in symmetric and asymmetric motifs of DNA, is under discussion.

Key words: methylation, cytosine, methyltransferase.

\section{О. М. Тищенко, О. В. Дубровна}

Метилтрансферази рослин

Резюме

В огляді узагальнено суцасні дані стосовно цитозин-С5-ДНК 
метилтрансфераз рослин. Наведено характеристику трьох різних класів цих ферментів - DnmtI/METI, Dnmt3 i CMT. Обговорюеться їхя передбачувана функція, пов'язана 3 підтримуючим та de nоvо метилуванням залишків цитозину в симетричних $і$ асиметричних мотивах дНК.

Ключові слова: метилування, цитозин, метилтрансферази.

\section{СПИСОК ЛИТЕРАТУРЫ}

1. Finnegan R. J., Genger R. K. Peacock W. J., Dennis E. S. DNA methylation in plants // Annu. Rev. Plant Physiol. Plant Mol. Biol.-1998.-49.-P. 223-247.

2. $\mathrm{Ng} H . \sim H .$, Bird A. DNA methylation and chromatin modification // Curr. Opin. Genet. Develop.-1999.-9.-P. 158163.

3. Bestor T. H. The DNA methyltransferase of mammals // Hum. Mol. Genet.-2000.-9.-mP. 2395-2402.

4. Finnegan E. J., Kovac K. A. Plant DNA methyltransfereses // Plant Mol. Biol.-2000.-43.-P. 189-201.

5. Cao X., Jacobsen S. Role of the Arabidopsis DRM methyltransfereses in de novo DNA methylation and gene silencing // Curr. Biol. $-2002 .-12 .-$ P. $1138-1144$.

6. Papa C. M., Springer N. M., Muszynski M. G., Meeley R., Kaeppler S. M. Maize chromomethylase Zea methyltransferase2 is required for CpNpG methylation // Plant Cell.2001.-13.-P. 1919-1928.

7. Finnegan E. J., Dennis E. S. Isolation and identification by sequence homology of putative cytosine methyltransferase from Arabidopsis thailana // Nucl. Acids Res.-1993.-21.P. $2383-2388$.

8. Wada Y., Ohya H., Yamaguchi Y., Koizumi N., Sano $H$. Preferential de novo methylation of cytosine residues in non-CpG sequences by a domains rearranged DNA methyltransferase from tobacco plants // J. Biol. Chem. -2003 . 278. -P. 42386-42393.

9. Genger R. K, Kovac K. A., Dennis E. S., Peacock W. J., Finnegan E. J. Multiple DNA methyltransfereses in Arabidopsis thaliana // Plant Mol. Biol.-1999.-41.-.P. 269-278.

10. Bernacchia G., Primo A., Giorgetti L., Pitto L., Cella R. Carrot DNA-methyltransferase is encoded by two classes of genes with differing patterns of expression // Plant J.1998.-13.-P. $317-329$.

11. Pradhan S., Cummings M., Roberts R. J., Adams R. L P. Isolation, characterization and baculovirus-mediated expression of the cDNA coding cytosine DNA methyltransferases from Pisum sativum // Nucl. Acids Res. -1998.-26.-P. 12141222.

12. Sterwad N., Kusano T., Sano $H$. Expression of ZmMET1, a gene encoding a DNA methyltransferase from maize, is associated not only with DNA replication in actively proliferating cells, but also with altered DNA methylation status in coilstressed quiescent // Nucl. Acids Res. -2000.-28. P. 3250-3259.

13. Cao X., Springer N. M., Muszynski M. G., Pillips R. L., Kaeppler S. M., Jacobson $S$. E. Conserved plant genes with similarly to mammalian de novo DNA methyltransferases // Proc. Nat. Acad. Sci. USA.-2000.- -97.-P. 4979-4984.

14. Chen $X$. DNA modification by methyltransferases // Curr. Opin. Struct. Biol.-1995.-5.-P. 4-10.

15. Sethmann S., Ceglowski P., Willert J., Iwanicka-Neuticka R., Trantner T. A., Walter $M$. ( $\phi$ ) BssHII A novel cytosine-C5DNA-methyitransferase with target-recognizing domains at separated localizations of the enzyme // EMBO J.-1999.18. -P. 3502-3509.
16. Mi S., Roberts R. J. How $M$. MspI and M.Hpall decide which base to methylate // Nucl. Acids Res.-1992.-20.P. 4811-4816.

17. Yen R. W. S., Vertino P. M., Nelkin B. D., Yu J. J., Deiry W. Isolation and characterization of the encoding human DNA methyltransferase // Nucl. Acids Res. 1992.-20.P. 2287-2291.

18. Bestor T., Laudano A., Mattaliano R., Ingram V. Cloning and sequencing of cDNA encoding DNA methyltransferase of mouse cells // J. Mol. Biol.-1988.-203.—P. 971-983.

19. Teerwanichpan P., Chandrasekharan M. B, Jiang Y., Narangajavana $J$., Hall $T$. C. Characterization of two rice DNA methyltransferase genes and RNAl-mediated reactivation of a silenced transgene in rice callus // Planta.-2004.-218. P. 337--349.

20. Wada Y., Miyamoto K., Kusano T., Sano $H$. Association between up- regulation of stress-responsive genes and hypomethylation of genomic DNA in tobacco plants // Mol. Genet Genomics. -2004.-271, N 6.-P. 658-666.

21. Leonhardt H., Page A. W., Weier H-U., Bestor T. H. A targeting sequences directs DNA methyltransferase to sites of DNA replication in mammalian nuclei // Cell, - 1992.-71.P. 865-873.

22. Robertson $K$. $L_{n}$, Jones $P$. DNA methylation: past, present and future directions // Carcinogenesis. $-2000,-21$. - P. 461 467.

23. Mimutinovic S., Zhuang Q., Niveleau A., Szyf M. Epigenomic Stress response. Knockdown of DNA methyltransferase1 triggers an intra-S-phase arrest of DNA replication and induction of stress response genes // J. Biol. Chem.-2003. - 278. P. $14985-14995$.

24. Vertino P. V., Sekowski J. A., Coll J. M., Applegren N., Ham S., Hickey $R$. J., Malkas $L . H$. DNMT1 is a component of a multiprotein DNA replication complex // Cell Cycle.--2002.1, N 6.-P. 416-423.

25. Okuwaki $M$., Verreault $A$. Maintenance DNA methylation of nucleosome core particles // J. Biol. Chem.-2004.-279.P. 2904-2912.

26. Ronemus M. J., Galbiati M., Ticknor C., Chen J., Dellaporta $S$. $L$. Demethylation - Induced development pleiotropy in Arabidopsis // Science.-1996.-273.-P. 654-656.

27. Finnegan R. J., Peacock W. J., Dennis E. S. Reduced DNA methylation in Arabidopsis thaliana results in abnormal plant development // Proc. Nat. Acad. Sci. USA, 1996.-93.P. 8449-8454.

28. Kankel M. W., Ramsey D. E., Stokes T. L, Flowers S. K, Haag J. R., Jeggeloh J. A., Riddle N. C., Verbsky M. L. Richards E. J. Arabidopsis MET1 cytosine methyltransferase mutant // Genetics.-2003.-163.-P. 1109-1122.

29. Li E., Bestor T. H., Jaenisch R. Targeted mutation of DNA methyltransferase gene results in embryonic lethality // Cell.1992.-69.-P. 915-926.

30. Bartee L, Bender J. Two Arabidopsis methylation-deficiency mutations confer only partial effects on methylated endogenous gene family // Nucl. Acids Res.-2001.-29.-P. 21272134.

31. Henikoff S., Comai L. A DNA methyltransferase homology with chromodomain exists in multiple forms in Arabidopsis // Genetics.-1998.-148.-P. 307-318.

32. Lindroth A. M., Cao X., Jackson J. P., Zilberman D., McCallum C. M., Henikoff S., Jacobsen S. E. Requirement of Chromo methylase 3 is required of $\mathrm{CpXpG}$ methylation // Science.-2001.-292.-P. 2077-2080.

33. Nakayama J., Rice J. C., Strahl B. D., Allis D. C. Grewal S. 
$L S$. Role of histone $\mathrm{H3}$ lysine 9 methylation in epigenetic control of heterochromatin assembly // Science.-2001. 292. -P. 110-113.

34. Jackson J. P., Lindroth A. M., Cao X., Jacobsen S. E. Control of CpNpG DNA methylation by the KRYPTONITE histone $H 3$ methyltransferase // Nature.-2002.-416.-P. 556-560.

35. Giannino D., Mele G., Cozza R., Bruno $L$, Testone $G$, Ticconi C., Bitonti M. B., Innocenti A. M., Mariotti $D$. Isolation and characterization of maintenance DNA methyItransferase gene from peach (Prunus persica [L] Batsch): transcript localization in vegetative and reproductive meristems of triple buids // J. Exp. Bot--2003.-54.-P. 2623-2633.

36. Tariq M., Saze H., Probst A. V., Lichota J., Habu Y., Paszkowski J. Erasure of $\mathrm{CpG}$ methylation in Apabidopsis alters patterns of histont $\mathrm{H3}$ methylation in heterochromatin // Proc. Nat. Acad. Sci. USA.-2003.-100.-P. 8823-8827.

37. Kato M., Miura A., Bender J., Jacobsen S. E., Kakutani T.
Role of CG and non-CG methylation in immobilization of transposons in Arabidopsis // Curr. Biol.-2003.-13.P. $421-426$.

38. Cao X., Aufsatz W., Zilberman D., Mette M. F., Huang $M$. S., Matzke M., Jacobsen S. E. Role of the DRM and CTM3 methyltransferases in RNA- directed DNA methylation // Curr. Biol. - 2003. - 13.-P. 2212-2217.

39. Mathieu O., Bender J. RNA-directed DNA methylation // J. Cell Sci.-2004.-117.-P. 4881-4888.

40. Hamilton A., Voinnet $O$, Chappell $L$, Baulcombe D. The classes of short interfering RNA in RNA silencing // EMBO J. -2002 . -21 . -P. $4671-4579$.

УДК 581.144:581.142:575.16:577.113.4 Надійинла до редакції 29.10.04 